\title{
What is Inclusive Didactics? Teachers' Understanding of Inclusive Didactics for Students with EBD in Swedish Mainstream Schools
}

\author{
Ulrika Gidlund $^{1} \&$ Lena Boström ${ }^{1}$ \\ ${ }^{1}$ Department of Education, Mid Sweden University, Sundsvall, Sweden \\ Correspondence: Ulrika Gidlund, Department of Education, Mid Sweden University, Holmgatan 10, 85170 \\ Sundsvall, Sweden. Tel: 46-010-142-8232. E-mail: ulrika.gidlund@miun.se
}

Received: November 15, 2016

Accepted: December 17, 2016

Online Published: April 29, 2017

doi:10.5539/ies.v10n5p87

URL: https://doi.org/10.5539/ies.v10n5p87

\begin{abstract}
Including students with emotional and behavioral difficulties (EBD) in general education is one of teachers' greatest challenges and make the dilemma of inclusion displays its most difficult side. This article contributes to the understanding of how teachers in Swedish mainstream schools understand the concept of inclusive didactics for students with EBD. This article employs a directed qualitative content analysis supplemented with descriptive statistics related to the categories of inclusive didactics. Didactic theory was the basis of the predefined categories by which the analysis was completed. Empirical data were collected through 6 focus-group interviews and 37 individual follow-up interviews. The findings indicate that three didactic aspects were dominant in teachers' understanding of inclusive didactics: Student(s), Methods, and Teacher. Less accentuated were Subject, Rhetoric and Interaction. Thus these teachers' understanding and previous research is not consistent. The overall conclusion is that the concept of inclusive didactics is complex, complicated, and difficult for teachers to relate to. The descriptions are both vague and simplistic and therefore difficult for teachers to implement. This article clearly highlights that teachers often feel frustrated and inadequate, and blame themselves for the students' deficiency and failure, thus concluding that strategies for distinct descriptions and teacher practices are needed.
\end{abstract}

Keywords: emotional and behavioral difficulties (EBD), inclusion, inclusive didactics, mainstream schools, teachers' understanding, qualitative content analysis

\section{Introduction}

Including students with emotional and behavioral difficulties (EBD) in general education is one of teachers' greatest challenges. The more EBD students threaten the classroom's stability, the more likely schools are to exclude them from the classroom or the school completely. When students' behaviors cause difficulties for their teachers the move toward inclusion becomes critical. Classroom and school exclusions of these students are often described as a pragmatic decision, necessary in order to implement inclusion and equity for the rest of the class (Dyson \& Millward, 2000).

Previous studies (Avramidis \& Norwish, 2002; de Boer, Pijl, \& Minnaert, 2011) indicated that students with EBD provide the most difficult challenges and manifest the dilemma of inclusion in its most difficult light, regardless of different school systems and cultures. The school is an arena of conflict among different requirements and needs that cannot be solved satisfactorily for everyone - but must be handled. Examples include the collective versus individual, the allocation of limited resources and supportive teaching at the expense of the regular teaching (Nilholm, 2005).

EBD are common, consisting of about $10 \%$ of students. Teachers encounter students whom they cannot understand or handle daily, and together with colleagues, they end up in situations in which they do not know how to act. This raises questions about how teachers understand their task to meet and include children with emotional and behavioral problems in their classrooms. Which discourses prevail and what tools and strategies to use to deal with these behaviors?

The Swedish curriculum for primary school, Lgr11 (Skolverket, 2011a), states that teachers have to relate to and have a special responsibility for students with EBD. For teachers to adhere to the guidelines of the curriculum, they often need to have a certain amount of knowledge and competence to work specifically with students with 
EBD to assure that teaching and learning work as well as possible for staff and all students. However the concepts of EBD, inclusion, and didactics all could be viewed as social constructs. In Sweden, teachers have shown frustration and insecurity about how to organize education for diversity, especially for students with EBD. In constructing inclusive education, teachers understand their teacher mission either as being knowledge-producing or offering and creating opportunities for equity, communication, and participation, rather than interlinking the two missions. They face problem to relate to inclusive didactics (Assarson, 2007). From a constructivist point of view, the teacher also constructs an understanding of EBD as being a problem for both the child and the rest of the class. These results come from a Swedish study of how mainstream teachers in a school that included children from special schools (i.e., mental and learning difficulties) constructed meaning of the Swedish concept "A School for All." There are no studies on how teachers in mainstream schools understand the concept of inclusive didactics for students with EBD in particular.

We want to frame this study within the bounds of this background. Our contribution to the field will be Swedish teachers' understanding of inclusive didactics in mainstream schools, specifically Grades 4-6 (i.e., 10- to 12-year-olds), which have not been studied yet. These students are interesting because the learning outcomes of the curriculum will be much higher and precise compared to Grades F-3, and the students are no longer young children whose out-of-line behavior is acceptable just because they are children. They will, during these years, be viewed as adolescents that should know how to behave in school. The overall aim of this article is to contribute to the understanding of how teachers in Swedish mainstream schools construct meaning of inclusive didactics for students with EBD. The specific research question is "How do mainstream teachers understand the concept of inclusive didactics for students with EBD?"

\subsection{Background}

This section will present this study's the key concepts and theoretical frameworks, followed by a review of previous research.

\subsubsection{Key Concepts}

The background and development of the key concepts behind this study are of great importance. Since the key concepts have no fixed meaning (rather are overflowed with meaning) the aim of this section is not to fix their meaning but to examine and reflect on their taken-for-granted meanings. The concepts discussed are not only a background or summary of policy documents and other relevant literature but also provide an overview and theoretical framework for this study.

\section{Emotional and Behavioral Difficulties (EBD)}

The concept of EBD is described by UNESCO (2009) as an umbrella term, regarded as imprecise and difficult to define, since it is on a continuum of behavior that challenges teachers: normal, albeit unacceptable, behaviors that indicate serious mental illness. EBD might manifest as introverted, passive, depressive, or aggressive behavioral or self-destructive tendencies. EBD is a subjectively perceived disorder rather than an objective one with definite and clearly defined characteristics that lead to the same diagnostic conclusions (Mundschenk \& Simpson, 2014). Even UNESCO (2009) has emphasized that what is considered socially acceptable behavior in one cultural, religious, or traditional context might be unacceptable in another. EBD are therefore highly sensitive to the background and situation of the children concerned.

The National Board of Health and Welfare in Sweden (Socialstyrelsen, 2010) defined behavioral problems similarly. It described behavior problems as instances in which a child repeatedly violates the rules, norms, or expectations of his/her childhood setting, and most behavioral problems are defined in terms of the values and norms of the social community. A certain act done by the child could be perceived to be a problem in one situation (e.g., a protest against the teacher's demands in the classroom) but not in another (e.g., a protest against a bully). Children with behavioral problems are described as being a "motley crew" (Socialstyrelsen, 2010, p. 13)

\section{Inclusion}

The concept of inclusion has come to signify the development of "Education for All" (UNESCO, 1990) all over the world for the last 25 years. The core of the concept of inclusion is based on human rights, equal opportunities, and social justice. The right of all children to education, including those children in significant need of special support, is described in several international documents. The concepts of inclusion and diversity are evident in sociology and often are used in special-education settings. Inclusion is no longer seen as an end station but rather as a process (Enslin \& Hedge, 2010; UNESCO, 2005).

Terms such as inclusion and inclusive education are not universally agreed upon, and it is therefore worth 
considering how their meaning is construed. Before the Salamanca Statement (UNESCO, 1994), the term inclusion was used primarily to refer to where a student with special-educational needs was to be educated and almost always was used in reference to special-educational needs. More recent reforms (UNESCO, 2005) have broadened the term's meaning to include the promotion of all students' presence, participation, acceptance, and achievement in mainstream schools (Booth \& Ainscow, 2002). Today, inclusion not only means that all students attend the same mainstream classes but also implies that differences among children should be valued and that difference is a natural condition of schooling. Inclusion, 'in this case means that children of all kinds attend the same classes, that diversity is celebrated within the classroom and children have a right to participate, to learn, and to build social relationships' (Nilholm, 2006, p. 438).

\section{The Didactic Triangle and Learning Environments in the Didactic room.}

Didactics includes factors that affect teaching and learning and the analysis and understanding of these factors. The field of research processes teaching and learning theory and practical considerations. In this study, we have chosen the model Didactic Triangle (Hoppman, 1997) in the Didactic room (Augustsson \& Boström, 2012). The didactic triangle is the core of didactic theory; It is a model for planning and reflecting on the teaching situation and consists of interactive and communicative interactions among three cornerstones and the relations among these three bearing functions, or axes (Künzli, 2000). The principles were already in Comenius's Didactica Magna (Kroksmark, 2008). This model facilitates describing and reflecting on the key factors that make up a teaching/learning situation and interrelating factors. The didactic room is the physical place where teaching and learning takes place (Augustsson \& Boström, 2012, 2016).

The cornerstones of the didactic triangle are Subject, Teacher, and Students, and the axes are Rhetoric, Methods and Interaction, which interact with each other in different ways, in various degrees, and in different contexts (Hoppman, 1997; see Figure 1). The Teacher cornerstone refers to teachers' professional and personal qualities, the Students cornerstone refers to learning at individual and group level and the Subject cornerstone refers to specific knowledge content. Interaction refers to the relationship between the teacher and the student/group, and it is communicative and relational. Rhetoric concerns how the teachers present the subject. Methods are about which teaching methods are offered or suit the situation (Ullström, 2009; Wahlström, 2015). Through these six aspects and the Learning Environment, the empirical data have been analyzed in relation to teachers' perceptions of inclusive education.

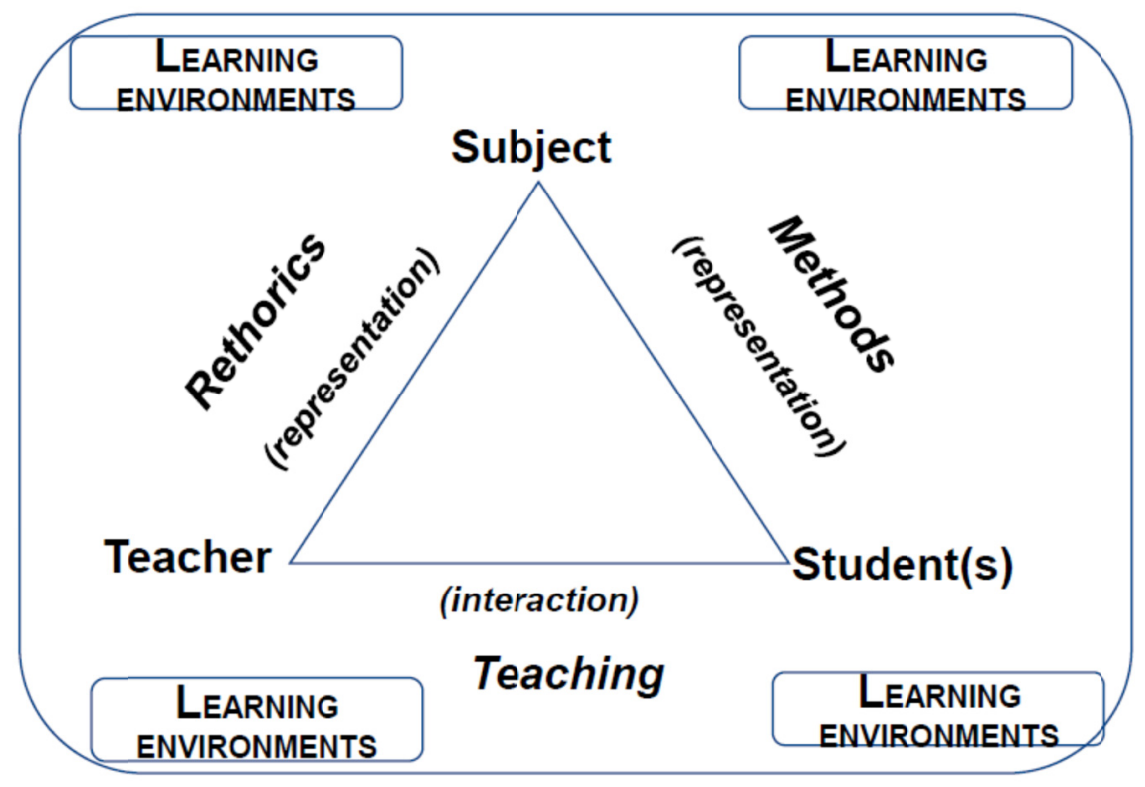

Figure 1. The didactic room with the didactic triangle and learning environments

When learning takes place in a specific room, a special learning environment pervades this room. Learning Environment is a broad concept, but we restrict this study to the physical learning environment, such as buildings and furniture, since the teachers of this study discussed it quite frequently. 


\subsection{Previous Research}

This section presents previous research on inclusive didactics for students with EBD in order to frame the research area.

Students with EBD are considered by teachers the most difficult students to include in mainstream classrooms. Research also has shown (Cefai \& Cooper, 2010) the fundamental differences between students' and teachers' views on school problems. These differences are particularly striking among students with EBD, since they are likely to be in conflict with the school because of their difficulties. Students blame their EBD on school-related factors, such as teasing and bullying by peers, teachers' attitudes, and learning difficulties. Teachers blame student characteristics, such as personality, attention, and family problems, for EBD and complain about the students' lack of motivation, defiance, and the way they disrupt lessons (Cefai \& Cooper, 2010; Gidlund, 2017). The second most-reported reason for teachers in the United States leaving the teaching occupation is dissatisfaction with students' discipline and behavior (poor salary being the first) and minor influence on student behavioral rules and sanctions (Ingersoll, 2003). Greene (2011) pointed out that half of all teachers end their profession within their first four years, and the main reason behind leaving is the relationship between children with behavioral problems and their parents.

Inclusive didactics is a social and political construction in which different discourses struggle to achieve dominance. Inclusive didactics, as an empty signifier open to a variety of definitions, is shaped by different groups in their quest for influence and power over the content and design of the school (Assarson, 2007). Swedish schools have the function to offer both criterion-referenced curriculum and create opportunities for equity, communication, and participation. In Assarson's (2007) study, teachers showed frustration and insecurity about how to organize education for diversity and variation. In constructing inclusive education, teachers understand their task either as having social implications or as mediating knowledge. Sometimes, these tasks even conflict each other. If inclusion is about increasing the participation of all learners in mainstream schools, then there is a need to address questions of classroom teaching and curriculum when considering inclusive practices (Norwich \& Lewis, 2005), and it is to that we now turn. Below some tools and strategies for students with EBD based on previous research will be presented.

Certain practices are known to be effective and frequently recommended, such as peer mediation, strategy instruction, mnemonics, study-skills training, organizational-skills training, hands-on curriculum materials, test-taking-skills training, comprehension training, self-advocacy-skills training, self-monitoring, or even general principles of effective instruction (Scruggs, Mastropieri, \& McDuffie, 2007). According to Humphrey (2009), effective strategies and approaches based on research and professional knowledge in the area of inclusion of students with EBD should allow increased opportunities for verbal participation and lessons with frequent but short breaks between activities. All tasks should be broken down into small, manageable chunks. Teachers should provide predictability, structure, and routine while minimizing distractions. Key information should be highlighted in bold or in a different color. Active experiments and concrete examples should be visual and provide models of completed work as a visual prompt of the goal state. Humphrey also mentioned the impact of applying cognitive and behavioral strategies, like positive expectations regarding ability, behavior, and motivation.

Nordic research has argued that the students' day will be clear and safe if teachers give them solid frames and regularity, and have firm rules that create a clear structure for the student. Teachers should know how to prepare children for situations that are difficult for them. Structure is important, and a predictability of what will happen during the school day provides students with security, such as when giving the student an individual schedule every morning (Hejlskov, 2012; Juul, 2005; Kadesjö, 2010). Arranging delimitation for the student, so that he/she is not disturbed by others is also mentioned by Juul (2005). Headphones with music or earplugs to reduce or weed out annoying sounds could be calming. Furthermore, many students with EBD have difficulties managing collective instructions. Therefore, it is important that teachers make eye or physical contact with students to get their attention, since all communication works best if the teacher addresses only the student and not the whole class.

A starting point for building relations is to listen to these students. In Cefai and Cooper's (2010) study, students stressed the need for more humane, inclusive, and relevant education. They praised the teachers who met them with care and understanding, listened to their concerns, and gave them support in relationships and learning. Another study based on students' voices found that students prefer teachers whom are flexible and open to their problems and prepared to cooperate with them in trying out different kinds of teaching solutions (Heimdahl-Mattson \& Roll-Pettersson, 2007). 
Concerning previous research about the didactic triangle, there is one literature review (Augustsson \& Boström, 2016) that identified patterns and trends concerning teachers' leadership in the didactic room. One corresponding result with significance for this study was that researchers' findings were distributed as following: method issues (34.2\%), teacher (23.7\%) subject (17\%) and student(s) (15.1\%). Another study related to this subject (Augustsson \& Boström, 2012), is a conceptual paper about leadership in the didactical room. The results showed that by using conscious didactic action skills, teachers can act more effectively and qualitatively when approaching new and unpredictable problem situations.

Previous studies of teachers' understanding of inclusive didactics and inclusive education have concluded that teachers face problems relating to inclusion (Avramidis \& Norwich, 2002; Cefai \& Cooper, 2010; de Boer et al., 2011; Hedegaard-Hansen, 2012). Because of the concept of inclusion's multiple meanings and implications for practice, teachers construct their teacher mission from a pragmatic position of getting things to work. Some teachers are even unaware of the term inclusion and the concept per se, but are expected to implement this policy regardless of their personal views and often without recourses (Dyson \& Millward, 2000; Lloyd, 2013; Takala, Haussttätter, Ahl, \& Head, 2012). Students who disturb the class are constructed as being a problem for both themselves and the rest of the class. The teachers construct their understanding of inclusion of students with EBD based on their own constructions of meaning and understanding in relation to how to make educational situations work out well (Assarson, 2007; Gidlund, 2017; Hedegaard-Hansen, 2011; Thomas \& Loxley, 2001).

\section{Method}

The overall aim of this article is to contribute to the understanding of how teachers in Swedish mainstream schools understand the concept of inclusive didactics for students with EBD.

\subsection{Directed Content Analysis}

A qualitative research design of directed content analysis was used to address the research questions (Hsieh \& Shannon, 2005). The key concept behind this approach is that existing theory guides the initial coding of categories - deductive category application (Mayring, 2000). Directed content analysis enables us to pay attention to the core concepts of didactic theory as a theoretical encoding scheme. According to Hsieh and Shannon (2005), "the findings from a directed content analysis offer supporting and non-supporting evidence for a theory" (p. 1282). The qualitative content analysis has been supplemented with descriptive statistics of the categories, which provide even clearer answers to the research questions. In this study, didactic theory is the basis of the predefined categories and codes by which the analysis is done. This approach allowed us to combine data from the theoretical literature as well as from the empirical literature (Whittemore \& Knafl, 2005), which also made the analysis more complex and difficult.

The ontological and epistemological premises underlying the study are social constructionism and the role of language in the social construction of the world. Reality is only accessible to us through categories, so knowledge and representations of the world are not reflections of reality, but rather products of our ways of categorizing the world. Our access to reality is therefore always through language. The reality exists, but it only gains meaning through discourse. The meaning in discourses also works to constitute and change the world (Winther Jørgensen \& Phillips, 2002).

\subsection{Sample and Data Collection Methods}

Data collection method is the focus group interviews with individual follow-up interviews based on stimulus texts. The empirical data collected through six focus group interviews with four to eight teachers of Grades 4-6 in six different mainstream schools and 37 individual follow-up interviews. The schools chosen all have different cultures and contexts due to their size, geographical characteristics, and socio-cultural, -economic, and -political backgrounds. The focus group interviews focused on the concept of inclusive didactics for students with EBD, and in the individual interviews, participants were asked to clarify, develop, or express those views that were discussed in the group or to express new views.

The empirical material for this study is thus based on six focus group interviews and 37 individual interviews conducted in 2015.The entire empirical materials consist of about six hours' worth of discussion, about one hour per focus group interview, centered on three main stimulus texts. Converted to a Word file in 11-point Calibri, the transcribed interviews fit on about 170 A4 pages.

Stimulus texts were used in the focus group interviews to encourage the interviewees to discuss the research topic. The stimulus texts and the interview questions posed were intended to make the topic under study discernible in that the interviewees, "through interpreting the stimulus text, are 'empowered' to express their social experience and cultural knowledge of the issue under question" (Törrönen, 2002, p. 345). The posed 
interview questions were used as resources to guide the interviewees to interpret the world constructed in the stimulus text in comparison to their own beliefs and experiences. All three stimulus texts used contained quotations from Socialstyrelsen (2010), Skollagen (2010: 800), and Skolverket (2011b) to encourage the interviewees to express their personal values and their ideal and subject positions in relation to the specific social and cultural contexts of schools. The third stimulus text specifically mentioned "inclusive didactics."

The study considered the Research Council's rules for good ethical research in the humanities and social sciences (Hermerén, 2011). The Research Council's ethical norms were followed in the study regarding individual protection of information, consent, confidentiality, and use. All teachers participated voluntarily in the study after a presentation and were assured of anonymity. Each individual was guaranteed anonymity through encoding. The findings are therefore not linked to the individuals.

\subsection{Procedure}

The selected research method involves interpretation of the content of texts or other verbal expressions by systematic categorization of themes and patterns - in this case, subjective and holistic interpretation of the parts of the text, text as a whole, and its context. In this study the manifest content is taken into account, and the interpretation is based on the rules for the encoding of the text.

In the analysis, great emphasis is placed on the participants' subjective understanding of the text (part, whole, and context). The idea behind conventional content analysis is that our beliefs construct and reflect the reality around us (Ahuvia, 2008).

The coding scheme was based on the didactic aspects (see Table 1). The coding instrument was tested in a research team. All the passages where the codes/categories appeared were added to the schedule. Such passages that could not be coded based on the schedule were recorded and then analyzed separately. They were named Other in the study. The categorization was analyzed and then presented along with text extracts (quotes) to strengthen the reliability, and the results are also presented quantitatively in the form of a frequency table.

We also employed descriptive statistics to consider frequencies in relation to the didactical aspects. The qualitative approach focused on qualitative aspects in all didactical aspects.

The analysis of all the transcribed interviews was performed in several steps. The first step was an "open" reading of each interview to obtain an overall impression of its content. In the second step, meaning units with reference to the participants' construction of inclusive didactics were identified from the transcribed data. A meaning unit consisted of one or more sentences or paragraphs of a narrative. In the third step, the interpretation of the underlying meaning was expressed in terms of codes and subcategories, and in the fourth step, we compared the outcome data and, through subsequent discussion and review, reached a consensus. The quality assurance procedure at this point once again required the two researchers to independently review the data. Each author read the other author's initial analysis. The condensations and codes were then subjected to critical discussion, which resulted in certain modifications of the codes. Thereafter, in the fifth step, the codes were analyzed and labelled into subthemes. Table 1 shows examples of the analysis process. After reading the analysis as a whole, the authors discussed and compared the findings until agreement was reached. The interviews in their entirety served as a point of reference throughout the analytical process when deeper understanding was needed of the meaning units, codes, and subcategories. To maintain scientific integrity, we paid great attention to validity during the integrative review phase.

Table 1. Example of the analysis process

\begin{tabular}{llll}
\hline Meaning unit & Code & Subcategory & Category \\
\hline $\begin{array}{l}\text { This student has other needs compared to the group. } \\
\begin{array}{l}\text { What I miss is the behavioral skills. I have teaching skills, but with these } \\
\text { children I need even more ... }\end{array}\end{array}$ & $\begin{array}{l}\text { Students' different } \\
\text { needs }\end{array}$ & $\begin{array}{l}\text { How these students work } \\
\text { and are }\end{array}$ & Student(s) \\
\hline $\begin{array}{l}\text { But it is how I should work. What should they do?! Are they supposed to do } \\
\text { what everybody else does? }\end{array}$ & Skills & Teacher \\
\hline
\end{tabular}

\section{Results}

This section outlines the outcomes and is structured around two levels of analysis: The first, a contextual-level distribution of didactical aspects, is followed by a content-level thematic analysis and discussion of the data in 
relation to didactical aspects.

\subsection{Contextual Level of Analysis}

Regarding didactic aspects, Table 2 shows that the teachers' descriptions of inclusive didactics mostly focused on Student(s), followed by Methods and Teacher. The categories with the lowest proportions were Interaction, Subject, and Rhetoric. The two additional categories, Learning Environment and Others, together comprise 16\% of the content of the teachers' statements.

Table 2. Didactical aspects

\begin{tabular}{lc}
\hline Didactical aspects & Percentage of statements (\%) \\
\hline Method & 22.2 \\
Subject & 5.4 \\
Teacher & 19.8 \\
Student(s) & 26.4 \\
Rhetoric & 4.1 \\
Interaction & 5.7 \\
Learning Environment & 6.8 \\
Others & 9.2 \\
\hline
\end{tabular}

\subsection{Content-Level of Analysis}

This section presents the content of the categories that has to do with the purpose and didactical aspects. The goal is to frame the seemingly separate aspects to offer an overview of what is addressed in the interviews.

\subsubsection{Didactical Aspects}

Listed below are the didactic content aspects of the interviews presented. The three dominant aspects, Student(s), Method, and Teachers, are first described separately, followed by the three didactic aspects of Subject, Rhetoric, and Interaction in a joint subchapter because they are of limited extent. Finally, the categories Other and Learning Environments are presented.

\section{Student(s)}

As mentioned earlier, the most dominant didactic aspect was the Students. A thematic analysis of the statements shows a fuzzy, homogeneous, and unclear picture of teachers' understanding of students with EBD.

Most comments were about how these students are and work. It is obvious that the students' ways of working and being vary a lot in terms of whether they have learning difficulties or not, concentration difficulties or not, various kinds of behavioral difficulties, different learning styles, and different behavioral styles, as well as whether they are high or low achievers. There is also variation in terms of cultural differences and/or whether they are trained in school behaviors and structures. One quotation that highlights the difficulty of defining this group is the following: "No, I don't know for sure. This is really hard since the range of behavioral difficulties is too large". "What they seem to agree on is nevertheless that students are unique individuals with different learning styles: "Because there is no standard since all children are unique. What will work on this child, will not work on that, and they cannot work together."

The majority of the comments describe different types of learning and concentration problems that are close to those of students in special schools, such as difficulties sitting still, listening and handling taking turns, and focusing, as well as lack of independence and social problems. On the contrary, that these students do not have learning difficulties; they have other learning styles, intelligences, or skills. They have great potential to grow if they are able to keep up and to feel that they are "normal."

Another subcategory is how to meet these students' need. "... doing in a way that suits everyone" is mentioned as a method of accommodating the students' differences and building on their strengths. Teachers do not "saw them off at their ankles" but assess them differently and help them strengthen their self-confidence and let them succeed. One teacher described an advantageous approach as following: "That they feel that they keep up with, that they feel that they understand. That they feel an involvement in what is happening in the classroom. I think. That it is not a too difficult level as well."

Further, teachers mentioned the importance of allowing students to work at their own level, but not to lower the 
knowledge requirements. The importance of giving them small goals, feedback, and encouragement was also mentioned. They have to experience that they are good enough and that they are not misunderstood. The importance of structure and transparency and the fact that these students have very little chance to succeed if the wrong method is used were also mentioned.

The student versus the group further complicates the picture. One problem is about individualizes for students with EBD in the class. Another is that these students cause problems in class because of their behavior or because they feel singled out. It seems easier for them to behave in a smaller group. Another aspect is that students with EBD are in need of a supportive adult.

\section{Methods}

Another dominant category in the teachers' discussions about inclusive didactics was Methods. There were four visible themes within this category: individualization, adaptation, structure, and simplification. The importance of individualization was mentioned in general terms but also with specifications. Some examples of methods were compensatory aids, computing, posters, spoken texts, concreteness, and reading aloud. Adaptation was mentioned together with individualization but also apart from it. Overall adaptation was mentioned generally and often in the discussions, but not problematized or specified to any great degree; see the quote below:

.... didactic inclusion, but it's all about that, what adaptations we make. So we constantly scan, okay, but then ... then maybe he/she can work with this material then, or you can sit there and work then or you collaborate with that student.

The importance that teaching is structured is a clear theme. For example, instructions should be transparent, clear, and written on the blackboard, preferably with bullet points. The day's schedule should be apparent for the students to show them what will happen during the day. The information should preferably be structured so that students can tick items off. Framing and routine are also important in this context. The quotations below exemplify the structure as an important aspect of the teacher's methods.

Understandably schedule, I think. Ticking off. "This is what you should do this lesson, or this week, or this day. So, you can erase that task if it is math," for example, or Swedish. "When I'm done with it, then I erase it. When I have reached that, then I know that I'm allowed to do something else." But the framing, it should be ... they must know what will happen next, to write on the blackboard what is happening, for them to know in advance.

To simplify and shorten the subject content is also a common method. Teachers can reduce the amount of information/text since it can be stressful for these students, and shorten and even delete specific parts. It is desirable only to give them the core of the subject content and peel away some parts. This may be facilitated by giving a joint lecture to begin with and then assigning various follow-up tasks. One other aspect in the discussions is that these students are not capable of discussion and analysis like the other children and that can be a reason for simplification. This is reflected in the quote below:

The others in the class, they fix to sit and discuss and analyze, "you think so, you think so. Yes, I understand it so." But not these children, they want to know, "What shall I do?" "Shall I read this and I'll do this task, and then it is finished?" Yes, we fix it, and then they get the other things to do. Can we talk about or discuss something else, huh, ... And it has worked well indeed for these rowdy students I have.

This might be a Catch 22: If students are not able to join the discussion but still sit in on lessons, it might lead to exclusion, as the following quote illustrates:

Then they get excluded. You have joint discussions, give some information jointly. . . . I mean, they do not keep up at all. I think that would be difficult.

\section{Teacher}

Four subthemes could be discerned regarding the teachers' role in didactic inclusion: thinking/reflection, emotions, skills, and collegial work.

Very clear in the interviews is that students with EBD occupy the teachers' thoughts to a large extent, both professionally as well as privately. What is expressed is that teachers really think and reflect on their teaching and the children, and that they need to think in a new and different way about these children to adapt as a teacher to them. They must work closely with them all the time not to lose touch. Also described is how students' performances are teachers' problems, and it is the teacher who fails if the student cannot manage. "Because it is we who are the problem. It is in that case I who fail if there is a student who cannot manage," one interviewee explained.

Teachers also expressed that they blame themselves for students' failure, as illustrated in the quote below: 
As much as I have turned out and in on myself. . . Thus, it is I who have made them fail. . . . and it is hard to take, because I have, like, blamed myself over and over again, and that is probably why I have been lying awake and thought new and thought differently and done differently.

Teachers expressed frustration and inadequacy in the interviews. There seem to be many difficulties to struggle with, and teachers suffer from pupils' failures. However, teachers have to "keep a cool head" and let the students' learning processes take time. The teaching profession with these students is about creating and maintaining confidence, choosing one' s conflicts, and maintaining the attitude "I do not accept your action, but I like you a lot."

Teachers who work with students with EBD also need additional skills. They require theoretical competence in behavioral and supervisory skills and knowledge of various disabilities in addition to more practical competence such as the ability to read students and balance educational options. Even the capacity to be open and to communicate with students is important. Another aspect of competence is to have the time and opportunity to focus on education, which they are trained for, and sort out those tasks that are peripheral in their everyday professional lives. Time for teaching and time for preparing and processing the lessons are called for.

Collegial work is of the greatest importance for teachers' work with this group of students. They prefer to have two adults in a class, to let one of them focus on the child/children in need of support. They can thus get the opportunity for reflection, support, and shared experience of the work. However, teachers have different personalities and have different competences and experiences.

Yes, one supports one another, asking and thinking like this, yes, "but how would you do if you had it this way, or if you had this problem in the class and so on." That is the way one supports each other, and I think that's good, actually. And then you look upon things differently, we're different and we work, of course, also with things in different ways.

A concrete example mentioned is the possibility to conduct collegial observations to get clearer pictures on educational practice. Collegial collaboration can also facilitate the development of a common set of values and a common professional language.

\section{Subject, Rhetoric, and Interaction}

The didactic aspect of the Subject was not discussed much in the interviews. The only subjects mentioned in passing were math (multiplication), Swedish, reading skills, science, and civics, as expressed in the following two comments:

The workbook for mathematics is, like, overloaded with information. And these students who do not fix that amount, for them it's hard to find anything else. But they do not usually sit by themselves with a history text or something, but you most often sit together.

Another aspect of the subject is the subject requirements of the curriculum and the problem that these children often do not fulfill them. Problems with national tests were also mentioned.

The didactic aspect of Interaction between teacher and student(s) was not mentioned very often either. The fact that relationships are important was pointed out, as were group dynamics and the fact that teachers need to "take a conscious grasp of this." A quote may illustrate the difficulty of relationships: "Difficulties with the social game is what it is all about."

The aspect of Rhetoric involves the teacher's way of presenting content to students. This aspect was not often expressed either. When it occurs, it is about where the teacher is placed and moves in the classroom, joint presentations when the teacher must address the whole group, and how the teacher can communicate "secretly" with students with EBD so that students do not feel singled out. Two distinct nonverbal communication patterns mentioned are that the teacher should write the schedule (and structure) on the board every day and that the teacher should sit a little to the side of the student during individual help.

\section{The Learning Environment and Other}

The Learning Environment certainly does not belong in the classic didactic aspects, but because it partly surrounds them in the didactic room (Augustsson \& Boström, 2014, 2016) and is a cornerstone of inclusion, we have chosen to categorize comments as such. It deals mostly with making the physical environment work satisfactorily by adjusting the classroom - for example, through noise reduction, screens, large windows, neutral colors, unadorned, earmuffs, and good space in the classroom. The need to have access to a small study room was also emphasized. One teacher gave an illustrative description of favorable premises: "great rooms so that one has proximity, thus one can have the groups adjacent and so on, so that you might go away but still be present on the whole without having to go too far away." 
Since almost $10 \%$ of the comments about didactic inclusion were about other things, we have chosen to make a separate category called Other. Many of the comments referred to resources in terms of personnel, need for reinforcements, and more time and assistance. Even students' upbringing, contact with parents, and parents' responsibilities were discussed, and some mentioned that something important has been lost from the world of school. Parent's attitudes and responsibilities were mentioned in relation to children with EBD who are constantly breaking rules. This is described in the quote below:

And it is the parents' influence and attitudes that has become different. . . I think that we very often work against the parents instead of with them - even though we want to work with them.

To sum up, while the teachers in this study were discussing inclusive didactics, they focused most on their students, their methods, and themselves as teachers. They also mentioned other didactic aspects, as well as aspects that do not belong to the didactic triangle but are still important for their work with students with EBD.

\section{Discussion}

The overall aim of this article was to contribute to the understanding of how teachers in Swedish mainstream schools understand the concept of inclusive didactics for students with EBD. We used a directed content analysis with a deductive approach in which the core concepts of the didactic theory guided the initial coding of the categories Students, Subject, and Teacher and Methods, Rhetoric, and Interaction with the addition of Learning Environment and the subcategory Other. The qualitative content analysis was supplemented with descriptive statistics of the categories, in order to provide a clearer answer to the research question.

First, we note that teachers do not have a clear and uniform image of the concept. Teachers mainly relate to and construct meaning from three of the six didactic aspects, namely Student(s), Methods, and Teacher. This diverges somewhat from the prominent role of Methods and Subject in previous research (cf. Augustsson \& Boström, 2016)

Most comments were to be found in the category Student(s), and they mostly pertained to how these students are and work and the teachers' difficulties defining this group (cf. UNESCO, 2009). The issue of placing the problem within the student has also been studied by Gidlund (2017). The student versus the group is also a discussed aspect within this category. Teachers worry about including these students since they make problems for themselves in the group and feel singled out.

This axis is discussed in relation to both the Teacher and the Subject (see Figure 1). The teachers claim they must have a special knowledge of meeting these students' needs, and the subject must be adapted to their level of knowledge and special needs. In the findings we identified special trends dealing with the subject that will be discussed in more detail in that subsection.

Concerning the didactical aspect Methods, the findings of this study, in line with the international literature (Humhrey 2009 \& Kadesjö, 2010; Juul, 2005; Scruggs, Mastropieri, \& McDuffie, 2007) suggests that it is important for teaching to be individualized, adapted, and structured and the subject simplified and shortened. There were apparent parallels among the teachers' descriptions of effective methodological tools and strategies and those described in previous research.

Regarding the teacher's role in didactic inclusion, the Teacher - Student relation was most expressed. Four subthemes could be discerned; think/reflect, emotions, skills, and the specific subtheme that deals with teacher teams called collegial work.

The discussion among the teachers about the Teacher-Student relation, and interaction closely resembled the findings of previous research. To create and maintain the students' confidence, to choose one's conflicts and be consistent (Cefai \& Coopers, 2010; Hejlskov, 2014; Humhrey 2009; Juul, 2005; Kadesjö, 2010). The teachers in this study, as mentioned in previous research, also ask and yearn for more knowledge and competencies (Avramidis \& Norwich, 2002; de Boer, Pijl, \& Minnaert, 2011; Takala, Haussttätter, Ahl, \& Head, 2012).

What is quite obvious and strongly expressed during the interviews is the teachers' frustration, inadequacy, and self-reproach. They blame themselves for the students' failure. Thus collegial work is expressed as something important for working with these students. Scruggs, Mastropieri, and McDuffie (2007) mentioned that teachers generally find co-teaching advantageous for students with special educational needs.

The didactic aspect of the Subject was not all that common in the interviews, but the subject requirements of the curriculum and the problem that these children often do not fulfill them were mentioned, as were problems with national tests. The teachers described these students as being in need of something else, subject requirements at their own level in order to feel good enough and competent. A paradox, however, is that they mention the importance of not lowering the knowledge requirements. The relation between subject and teacher, or Rhetoric, 
was mentioned even less.

The fact that $16 \%$ of the comments about didactic inclusion were about the Learning Environment and Other-including both the lack of and need for adapted classroom resources in terms of personnel, time, and assistance - reveals that the teachers' frustration with being told to do something they cannot do for practical and economic reasons is evident. Even upbringing and parents' responsibilities were mentioned to be important factors in including students with EBD in Swedish mainstream schools.

\subsection{Conclusion}

In this article, we have presented the three didactic aspects that were dominant in teachers' understanding of inclusive didactics, namely the Student(s), Methods, and Teacher. Less accentuated were the Subject, Rhetoric, and Interaction. The Learning Environment and the statements that we named Other because they could not be traced to the core of didactics were found quite often in the discussions.

The overall conclusion is that the concept of inclusive didactics is complex, complicated, and difficult for teachers to relate to. The descriptions are both vague and simplistic and therefore difficult for the teachers to implement. The understanding of inclusive education is derived from a special educational paradigm, where the issues most attention is given to segregated learning with students with disabilities.

Another conclusion of this analysis is that the Subject was seldom mentioned when the teachers were discussing inclusive didactics because they know that the knowledge requirements of the Swedish curriculum cannot be altered. In Sweden the development has gone towards a much more firm and rigid one. This could be explained by Sweden's change of government and curriculum in a much more strict direction, and further by the establishment of state-controlled inspections of schools in order to, among other missions, control the fulfillment of the curriculum's knowledge requirement.

Our third conclusion is that when the teachers discussed effective methods for inclusive didactics, they mentioned what previous research and "hand-books" written by experts claim to be the most effective for these students. They said what is best to do at the same time as they explained the difficulties of doing this without the right resources, or with no resources at all.

Our final conclusion is that teachers want to do more. They want to know how to best meet these students' needs but feel frustrated and inadequate and blame themselves for the students' deficiency and failure.

In this context, it should be noted that the research front and these teachers' understandings are not synchronized. The question is whether there are competing discourses. Clearly, more research is needed to explore teachers' understanding of inclusive didactics for students with EBD. We need to know more about students with EBD, including why and how they differ from other students. Research may also help to develop new methods that will be both effective for these students and manageable for teachers and schools given the available, and for the time being prevailing, resources.

Research needs to highlight and illuminate the teachers' frustration, what they feel, and how they feel. Could a more elaborated collegial work and/or co-teaching model be beneficial for the teachers working with these students? More research could also be carried out on the effects of professional consultation for teachers working with students with EBD, and what professional help is fruitful in such a situation.

\section{References}

Ahuvia, A. (2008). Traditional, interpretative, and reception based content analyses: Improving the ability of content analysis to address issues of pragmatic and theoretical concern. In R. Franzosi (Ed.), Content analysis (Vol. 1, pp. 183-202). London, United Kingdom: SAGE.

Assarson, I. (2007). Talet om en skola för alla: Pedagogers meningskonstruktion i ett politiskt uppdrag. Diss. Malmö: Lärarutbildningen, Malmö högskola.

Augustsson, G., \& Boström, L. (2012). A theoretical framework about leadership perspectives and leadership styles in the didactic room. International Journal of Human Resource Studies, 2(4), 166-186. https://doi.org/10.5296/ijhrs.v2i4.2865

Augustsson, G., \& Boström, L. (2016). Teacher's leadership in the didactic room: A systematic literature review of international research. Acta Didactica, 10(9), 1-19.

Avramidis, E., \& Norwish, B. (2002). Teachers' attitudes towards integration/inclusion: A review of the literature. European Journal of Special Needs Education, 17(2), 129-147. https://doi.org/10.1080/08856250210129056 
Booth, T., \& M. Ainscow. (2002). Index for inclusion. Developing learning and participation in schools. Bristol: Centre for Studies on Inclusive Education.

Cefai, C., \& Cooper, P. (2010). Students without voices: The unheard accounts of secondary school students with social, emotional and behavior difficulties. European Journal of Special Needs Education, 25(2), 183-198. https://doi.org/10.1080/08856251003658702

de Boer, A., Pijl, S. J., \& Minnaert, A. (2011). Regular primary schoolteachers' attitudes towards inclusive education: a review of the literature. International Journal of Inclusive Education, 15(3), 331-353. https://doi.org/10.1080/13603110903030089

Dyson, A., \& Millward, A. (2000). Schools and special needs. Issues of innovation and inclusion. London: Paul Chapman. https://doi.org/10.4135/9781446219423

Enslin, P., \& Hedge, N. (2010). Inclusion and diversity. In R. Bailey, R. Barrow, D. Carr, \& C. MacCarthy (Eds.), The Sage Handbook of Philosophy of Education (pp. 385-401). London: Sage. https://doi.org/10.4135/9781446200872.n26

Gidlund, U. (in review). Teachers' understanding of emotional and behavioral difficulties (EBD) in Sweden. What is the problem? Pedagogisk Psykologiskt Tidskrift.

Greene, R. W. (2011). Vilse i skolan: hur vi kan hjälpa barn med beteendeproblem att hitta rätt. 2. uppl. Lund: Studentlitteratur.

Hedegaard-Hansen, J. (2012). Limits to inclusion. International Journal of Inclusive Education, 16(1), 89-98. https://doi.org/10.1080/13603111003671632

Heimdahl-Mattson, E., \& Roll-Pettersson, L. (2007). Segregated groups or inclusive education? An interview study with students experiencing failure in reading and writing. Scandinavian Journal of Educational Research, 51(3), 239-252. https://doi.org/10.1080/00313830701356109

Hejlskov, B. (2014). Problemskapande beteende vid utvecklingsmässiga funktionshinder. (uppl. 1:14). Lund: Studentlitteratur AB.

Hermerén, G. (2011). God forskningssed [Good research]. Stockholm: Vetenskapsrådet. Retrieved from http://www.cm.se/webbshop_vr/pdfer/2011_01.pdf

Hoppman, S. (1997). Wolfgang Klafki och den tyska didaktiken. In M. Uljens (Ed.). Didaktik (pp. 198-214). Lund: Studentlitteratur.

Hsieh, H., \& Shannon, S. E. (2005). Three approaches to qualitative content analysis. Qualitative Health Research, 15(9), 1277-1288. https://doi.org/10.1177/1049732305276687

Humphrey, N. (2009). Including students with attention-deficit/hyperactivity disorder in mainstream schools. British Journal of Special Education, 36(1), 20-25. https://doi.org/10.1111/j.1467-8578.2008.00415.x

Ingersoll, R. M. (2003). Is there really a teacher shortage? Seattle, WA: Center for the Study of Teaching and Policy, University of Washington. https://doi.org/10.1037/e382722004-001

Juul, K. (2005). Barn med uppmärksamhetsstörningar. Lund: Studentlitteratur.

Kadesjö, B. (2010). Barn som utmanar: barn med ADHD och andra beteendeproblem. Stockholm: Socialstyrelsen. Retrieved from http://www.socialstyrelsen.se/lists/artikelkatalog/attachments/17951/2010-3 -6.pdf

Kroksmark, T. (2008). Didactica Manga-Stora undervisningsläran. Lund: Studentlitteratur.

Künzli, R. (2000). German Didaktik: Models of representation, of intercourse, and of experience. In I. Westbury, S. Hopmann, \& K. Riquarts (Eds.), Teaching as a reflective practice: The German Didaktik tradition (pp. 41-54). Mahwah, N.J.: L. Erlbaum Associates. https://doi.org/10.4324/9780203357781

Lloyd, C. (2013). The Erasmus Mundus programme: Providing opportunities to develop a better understanding about inclusion and inclusive practice through an international collaborative programme of study. $\begin{array}{llll}\text { International Journal of Inclusive } & \text { Education, }\end{array}$ https://doi.org/10.1080/13603116.2011.651826

Mayring, P. (2000). Qualitative content analysis. Forum: Qualitative Social Research, 1(2).

Mundschenk, D., \& Simpson, R. (2014). Defining emotional or behavioral disorders: The quest for affirmation. In P. Gardner, J. M. Kauffman, \& J. Elliott (Eds.), The SAGE Handbook of Emotional and Behavioral 
Difficulties (pp. 43-54). London, England: SAGE. https://doi.org/10.4135/9781446247525.n4

Nilholm, C. (2005). Specialpedagogik - Vilka är de grundläggande perspektiven? Pedagogisk forskning $i$ Sverige, 10(2), 124-138.

Nilholm, C. (2006). Special education, inclusion and democracy. European Journal of Special Needs Education, 21(4), 431-445. https://doi.org/10.1080/08856250600957905

Norwich, B., \& Lewis, A. (2005) How specialized is teaching students with disabilities and difficulties? In A. Lewis and B. Norwich (Eds), Special Teaching for Special Children? Buckingham: Open University Press.

Scruggs, T. E., Masttopieti, M. A., \& McDuffie, K. A. (2007). Co-teaching in inclusive classrooms: A metasynthesis of qualitative research. Council for Exceptional Children, 73(4), 392-416. https://doi.org/10.1177/001440290707300401

Skolverket. (2010). 800. Skollag. Stockholm, Sweden: Utbildningsdepartementet.

Skolverket. (2011a). Läroplan för grundskolan, förskoleklassen och fritidshemmet 2011. Stockholm: Skolverket.

Skolverket. (2011b). Särskilt stöd i grundskolan. En sammanställning av senare års forskning och utvärdering. Stockholm, Sweden: Skolverket.

Socialstyrelsen. (2010). Barn som utmanar: Barn med ADHD och andra beteendeproblem. Retrieved from http://www.socialstyrelsen.se/publikationer2010/2010-3-6

Takala, M., Haussttätter, R. H., Ahl, A., \& Head, G. (2012). Inclusion seen by student teachers in special education: Differences among Finnish, Norwegian and Swedish students. European Journal of Teacher Education, 35(3), 305-325. https://doi.org/10.1080/02619768.2011.654333

Thomas, G., \& Loxley, A. (2001). Deconstructing special education and constructing inclusion. Philadelphia: Open University Press.

Törrönen, J. (2002). Semiotic theory on qualitative interviewing using stimulus texts. Qualitative Research, 2(3), 343-362. https://doi.org/10.1177/146879410200200304

Ullström, S.-0. (2009). Ämnesdidaktik som bro och vetenskap. In Schullerqvist, B., Ullström, M. \& Ullström, S. (Eds.). Ämnesdidaktiska brobyggen - didaktiska perspektiv inom lärande och forskning. s.10-23. Karlstad: Karlstad University Press.

UNESCO. (1990). World declaration on education for all and framework for action to meet basic learning needs. International Consultative Forum on Education for All. Paris: UNESCO.

UNESCO. (1994). The Salamanca statement and framework for action on special needs education. Paris: UNESCO.

UNESCO. (2005). Guidelines for inclusion: Ensuring access to education for all. Paris: UNESCO.

UNESCO. (2009). Embracing diversity: Toolkit for creating inclusive, learning friendly environments specialized (Booklet 3). Paris, France: UNESCO.

Wahlström, N. (2015). Läroplansteori och didaktik. Lund. Gleerups.

Whittemore, R., \& Knafl, K. (2005). The integrative review: Updated methodology. Journal of Advanced Nursing, 52(5), 546-553. https://doi.org/10.1111/j.1365-2648.2005.03621.x

Winther Jørgensen, M., \& Phillips, L. (2002). Discourse analysis as theory and method. London, England: Sage. https://doi.org/10.4135/9781849208871

\section{Copyrights}

Copyright for this article is retained by the author(s), with first publication rights granted to the journal.

This is an open-access article distributed under the terms and conditions of the Creative Commons Attribution license (http://creativecommons.org/licenses/by/4.0/). 